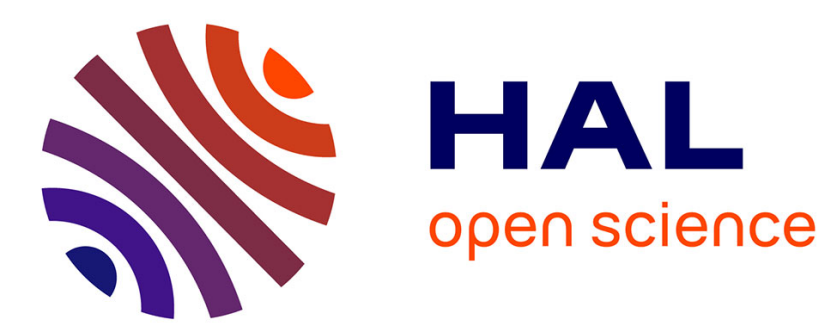

\title{
WHICH SIDE OF THE COIN? THE REGIONAL GOVERNANCE OF SCIENCE AND INNOVATION
}

Knut Koschatzky, Henning Kroll

\section{To cite this version:}

Knut Koschatzky, Henning Kroll. WHICH SIDE OF THE COIN? THE REGIONAL GOVERNANCE OF SCIENCE AND INNOVATION. Regional Studies, 2007, 41 (08), pp.1115-1127. 10.1080/00343400701530857 . hal-00514677

\section{HAL Id: hal-00514677 \\ https://hal.science/hal-00514677}

Submitted on 3 Sep 2010

HAL is a multi-disciplinary open access archive for the deposit and dissemination of scientific research documents, whether they are published or not. The documents may come from teaching and research institutions in France or abroad, or from public or private research centers.
L'archive ouverte pluridisciplinaire HAL, est destinée au dépôt et à la diffusion de documents scientifiques de niveau recherche, publiés ou non, émanant des établissements d'enseignement et de recherche français ou étrangers, des laboratoires publics ou privés. 


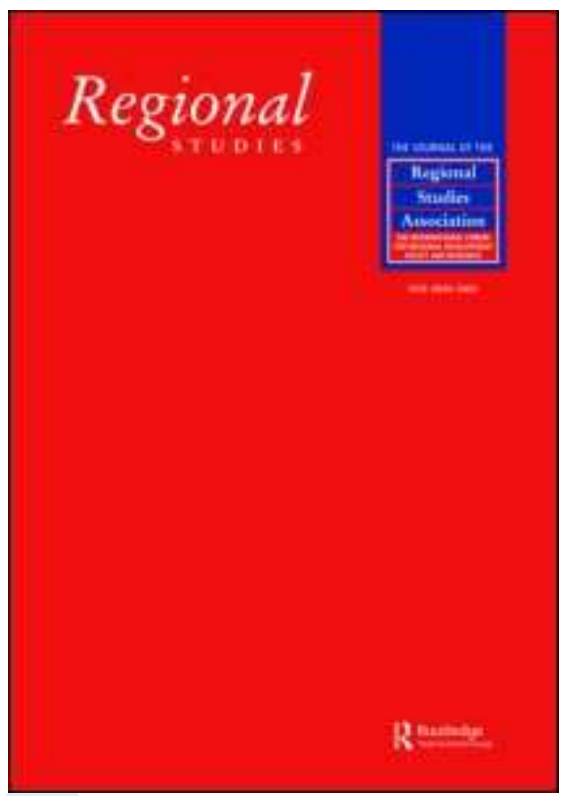

\section{WHICH SIDE OF THE COIN? THE REGIONAL GOVERNANCE OF SCIENCE AND INNOVATION}

\begin{tabular}{|r|l|}
\hline Journal: & Regional Studies \\
\hline Manuscript ID: & CRES-2006-0100.R2 \\
\hline Manuscript Type: & Main Section \\
\hline JEL codes: & $\begin{array}{l}\text { H70 - General < H7 - State and Local } \\
\text { Government|Intergovernmental Relations < H - Public Economics, } \\
\text { Ond Development < O - Economic Development, Technological } \\
\text { Change, and Growth, R58 - Regional Development Policy }<\text { R5 - } \\
\text { Regional Government Analysis < R - Urban, Rural, and Regional } \\
\text { Economics }\end{array}$ \\
\hline Keywords: & $\begin{array}{l}\text { Regional governance , Science policy, Strategic intelligence, Multi- } \\
\text { level govern-ance, Federal system, Bremen }\end{array}$ \\
\hline
\end{tabular}

\section{SCHOLARONE \\ Manuscripts}




\title{
WHICH SIDE OF THE COIN? THE REGIONAL GOVERNANCE OF SCIENCE AND INNOVATION
}

\author{
Knut Koschatzky, Henning Kroll \\ Fraunhofer Institute for Systems and Innovation Research \\ Breslauer Strasse 48, 76139 Karlsruhe, Germany \\ Email: knut.koschatzky@isi.fraunhofer.de, henning.kroll@isi.fraunhofer.de
}

\begin{abstract}
:
The paper deals with the impact of recent trends in the devolution of political powers in science, technology and innovation policies. It argues that a number of problems are associated with this regionalisation because the emerging multi-level governance structures turn political action into a complex bargaining process between actor groups with partially conflicting interests. The paper sketches the theoretical potentials and limitations of science, technology and innovation policy designed at the regional level. Based on regional evidence from the German federal system, it demonstrates which policy aspects are suitable for devolution to regional governments and how they can be integrated in multi-level governance structures.
\end{abstract}

\section{Key Words:}

Regional governance, Science policy, Strategic intelligence, Multi-level governance, Federal system, Bremen 
2

\section{Zusammenfassung}

Der Beitrag befasst sich mit der Bedeutung der Dezentralisierung politischer Entscheidungsbefugnisse in der Wissenschafts-, Technologie- und Innovationspolitik, in dem er sich mit den Problemen und Chancen dieser Regionalisierung auseinander setzt. Es wird die These vertreten, dass durch die Multi-Ebenen-Governance Strukturen politisches Handeln zunehmend zu einem komplexen Aushandlungsprozess zwischen den beteiligten Akteursgruppen mit teilweise konfligierenden Interessen wird. Vor diesem Hintergrund umreißt der Beitrag die theoretischen Potenziale und Grenzen von auf der regionalen Ebene gestalteter Wissenschafts-, Technologie- und Innovationspolitik. Basierend auf regionalen Beispielen aus dem deutschen föderalen System zeigt das Papier auf, welche Politikmaßnahmen geeignet für die Übertragung an regionale Regierungen sind und wie sie in die Multi-Ebenen-Governance Strukturen integriert werden können.

Regionale Governance, Wissenschaftspolitik, strategische Intelligenz, Multi-EbenenGovernance, föderales System, Bremen

JEL classifications: H70, O38, R58 
3

\section{INTRODUCTION AND OBJECTIVES}

Theoretical concepts such as the innovation system (EDQUIST, 2005) and the triplehelix approach (ETZKOWITZ and LEYDESDORFF, 2000) have demonstrated that innovation activities are not determined by economic forces alone, but crucially regulated and enabled by the governance structures they are embedded in.

Similarly, the theoretical debate in both Economic Geography and Regional Science has long established the notion that the innovation activities addressed by science, technology and innovation (STI) policies are complex interactive processes which are anchored in different ways at different spatial scales (cf. e.g. BUNNELL and COE, 2001, Kline and Rosenberg, 1986). The need to study the practical implications of this multi-level nature of innovation processes is raising new issues for debate since science, technology and innovation policy making has become subject to processes of regionalisation and devolution (KOSCHATZKY, 2005a).

National idiosyncrasies in the devolution of political powers to lower hierarchical levels continue to exist and have gained momentum in recent years (e.g. COLE and LOUGHLin, 2003; COOKe et al., 2003; LyALL and TAIT, 2004; see also JONES et al., 2005). This is the case in countries such as Germany, Italy and Spain where historic incidents have led to the establishment of decentralised policy decision systems, as much as in countries with recent devolution processes (CRESPY ET AL, THIS ISSUE. KITAGAWA, THIS ISSUE). The diversification of scales of governance results in the inclusion of conflicting policy objectives in the bargaining process. The focus of regionally designed science, technology and innovation policy is naturally often biased toward regional development objectives. Policies designed at the national level, in contrast, will 
have to focus at the technological performance of the national economy as a whole. Such specialised profiling at a national scale, however, could run counter to the interests of regional actors, who pursue the interests of their particular region and are therefore unwilling to renounce their support for certain aspects of their local economic profile. While the very nature of economic activities in innovative sectors very often suggests agglomeration and regional specialisation as a worthwhile national policy target, this conclusion will only reluctantly be accepted by regional policy makers in more peripheral regions.

The fact that national policy makers can no longer simply override the interests of regional actors has established a multi-level, multi-actor governance structure in which top-down policy design has been replaced by bargaining and substantial regional autonomy. This paper therefore aims to demonstrate the strengths, weaknesses and limitations of regional approaches in science, technology and innovation policy and to suggest possible modes of their integration in multi-level governance structures that allow for both an effective and efficient execution of policy decisions at the regional level and the creation of sensible outcomes at the national level (NAUWELAERS and WINTJES, 2003).

The argument put forward in this paper is twofold: firstly it is argued that, while it is indeed expedient to allocate resources and competences to regional governments to enable them to implement regionally designed science, technology and innovation policies, this alone will oftentimes not be sufficient. In order to reconcile the objectives of the devolution process with those of national STI policy, it is no less important to integrate regional policy actors in a multi-level governance process co-ordinated at the national level (COOKE, 2002a, pp. 55-56). Secondly it will be argued that some aspects of 
the innovation process can more effectively be addressed by science, technology and innovation policy designed at the regional level than others. Consequently, it is necessary to clearly distinguish between different aspects of science, technology and innovation policy before assessing the appropriateness of their regionalisation.

\section{GOVERNANCE FROM AN ECONOMIC AND POLICY PERSPECTIVE}

The term governance is key to the theoretical discussion about the importance of the role that policy and politics play for innovation systems (COOKE, 2002a, 2002b; COOKE et al. 2004). From a political science viewpoint, governance refers to the analysis of the balance of power in relationships and thus to collective action in different fields of activity (FÜRST, 2001, p. 371). According to a definition of governance given by the COMmission ON Global Governance $(1995$, p. 4), it "...is the sum of the many ways individuals and institutions, public and private, manage their common affairs. It is a continuing process through which conflicting or diverse interests may be accommodated and cooperative action may be taken. It includes formal institutions and regimes empowered to enforce compliance, as well as informal arrangements that people and institutions either have agreed to or perceive to be in their interest."

Beyond issues of definition, this section aims to clarify our understanding of the nature of the governance processes relevant for STI policy. In recent years, the term "multi-actor innovation policy arenas" was introduced into the debate about (innovation) policy concepts and governance (KuHLMAnN, 2001, p. 961). It aims to illustrate that STI policy is not characterised by top-down decision-making, but results from networking and bargaining between different societal actors, interest coalitions and systems. In such systems there is usually not one dominant player, but a policy arena made 
up of a variety of political, corporate, social and scientific bodies. Multi-level governance relationships can thus be understood as the sharing and coordination of political authority across several levels of government (KOHLER-KoCH, 1996; BENZ and EBERLEIN, 1999).

\section{REGIONAL GOVERNANCE OF SCIENCE AND RESEARCH}

In the course of both European integration and the growing significance of regional and local identity, policy measures designed by regional governments have gained importance. This is not only the case for policies aiming to equalise the regional standard of living, but also in the field of policies aiming to strengthen regional development through the upgrading of innovative potentials at a regional level (SWYNGEDOUW, 2004). Despite the trend towards regionalisation, however, the existing set-up of regional entities usually persists. While powers are increasingly being transferred to regional actors, most of these actors are affiliated to pre-existing administrative entities (for Germany cf. FÜRST, 2006).

From a conceptual perspective, the heuristic model of the regional innovation system (ASHEIM and GERTLER, 2005; IAMMARINO, 2005) provides a suitable basis to analyse the contextual structures of regional governance in science, technology and innovation policy. In this model, the analytical perspective aims at governance structures and policy measures at the regional level without denying their embeddedness in the larger context of a national and even supranational system of innovation (cf. BRACZYK and HEIDENREICH, 1998; COOKE et al., 2000). Regional innovation systems are not determined by regional governance alone, but firmly integrated in multi-level governance structures. This is especially important for regional innovation systems which are domi- 
nated by public research activities and where the development of science and innovation activities can thus more or less directly be controlled through policy measures (COOKE, 2001).

While the newly emerged multi-level governance system has created opportunities for the integration of regionally-anchored innovation systems in globally operating science, technological and enterprise systems (cf. COOKE, 2002b, pp. 136-137), it has simultaneously increased interdependencies and thus the complexity of STI policy making.

In such a context, STI policy will profit if strategic intelligence and a capacity for policy learning capabilities are present in policy planning. Strategic intelligence is "...a set of - often distributed - sources of information and explorative as well as analytical (theoretical, heuristic, methodological) tools employed to produce useful insight in the actual or potential costs and effects of public or private policy and management" (Kuhlmann, 2002, p. 17). According to NAUWElaERs (2000), the "capacity for policy learning" can be understood as "... the capacity of policy-makers to grasp the trajectories taken by firms in their knowledge governance modes (...) and the capacity to respond to such changes by developing flexible policy approaches in instruments."

More precisely, the design of an efficient regional STI policy requires a combination of regional intelligence (i.e. the ability to understand the local socio-economic context and enterprises' needs) with strategic intelligence and policy-learning capabilities (i.e. the ability to set political goals and develop appropriate policy instruments), in order to avoid "...undesirable volatility in the policy system" (NAUWELAERS and WINTJES, 2003, p. 201). The newly emerged multi-level governance system thus creates "political opportunity structures" (FÜRST, 2001, p. 375) that represent a seedbed for successful re- 
gional governance, because STI policy design needs regional intelligence. Other than with regional intelligence, however, regional actors will often not be able to supply sufficient strategic intelligence and policy-learning capabilities to design efficient policy measures. Consequently, efficient STI policies can in most cases not be designed by regional actors alone, who may involuntarily misallocate resources due to a lack of information. From a national perspective, such isolated agenda setting is to be avoided since it may create redundancies that undermine the competitiveness of the national and even the supra-national (European) innovation system (EUROPEAN COMMISSION, 2005).

In a multi-level governance system, however, co-ordination from the national level need, should and can no longer take the form of central top-down co-ordination. Hence, modern forms of national level policy initiatives, such as nation-wide competitions for funding, do not tell the regional actors how to design their policies, but provide information that can help them to assess their own programs and thus provide guidance for independent policy decisions at the regional level (see also CRESPY ET AL, THIS ISSUE). In a multi-level governance system, openness and the regular exchange with STI governance actors on the national level therefore represent essential criteria for the efficient design of STI policies at the regional level.

Motivated by a regional development agenda, however, regional science, technology and innovation policy in practice typically aims at the following three key objectives (CHARLES et al. 2004, p. 13):

- Setting regional priorities for research on the basis of small units of excellence not necessarily recognised on the national scale.

- Negotiating with central actors to shape central policies for the benefits of their 
regions.

- Building linkages between all elements of the regional science system to further innovation, commercialisation and technology transfer.

Interestingly, these key objectives differ strongly in terms of their compatibility with efficient multi-level science, technology and innovation governance. While some offer substantial potentials for inter-level co-operation based on complementary competencies at the regional and the national scale, others point to potential conflicts of interest between the national and regional level.

- "Units of excellence" not even recognised on a national scale may be an important asset for regional policy makers. However, they do not improve the efficiency of the national innovation system as a whole and are thus irrelevant for national innovation policy. Consequently, this field will likely be an area characterised by persistent conflicts of interest between national and regional actors.

- Similarly, negotiations aimed at attracting funds for a certain region can only be attractive to a national decision maker if the respective region has a potential to contribute to the overall efficiency of the national innovation system. This, however, is not the case for all regions per se. It can nevertheless be assured by certain measures at the national level such as interregional competitions for national funding.

- The building of linkages in the regional innovation system, to the contrary, is an appropriate playing ground for regional policy makers who in this field can tap into regional intelligence inaccessible to others and thereby activate potentials connected to proximity and networking. 
It is this constant need for differentiation that makes the design of STI policies for multi-level governance relationships both complex and challenging.

\section{DIFFERENT KINDS OF POLICIES AS STARTING POINTS}

With respect to the above, it is necessary to specify certain criteria defining appropriate policy fields as a playing ground for regional STI policy makers. To this end, it can be helpful to distinguish between the three elements of science, technology and innovation policy, because they address different issues and target groups, provide different starting points for regional policy-making, and are thus contingent on different premises. One important rationale that should be taken into account in this context are the appropriate financial resources for policy making. This relates to the question of whether the region that considers implementing certain policy measures is legally and practically able to cover the resulting expenses.

For a long time, science policy was regarded as a national and even international task of managing or prioritising scientific research, of establishing a research infrastructure to fit the needs of national research objectives and to safeguard the necessary supply of well-educated human capital able to advance scientific knowledge (EDQUIST, 2005). The modernisation of universities, the establishment of new research organisations or investments in large research facilities were some of the major measures taken by national science policy, sometimes in international cooperation. Although these measures had regional effects, the respective policies were designed at a national scale. Recently, however, science policy became an explicit issue at the regional level. This is now the case in countries in which regions have long had a certain autonomy in educational matters, e.g. in the German Länder, as well as in countries with more recent pro- 
nounced devolution processes like the UK (PERRY, THIS ISSUE) or even Japan (KITAGAWA, THIS ISSUE).

The terms innovation policy and technology policy are often used synonymously, although certain differences exist. Technology policy is understood as the "... policy concentrated on scientific-technical areas" (MEYER-KRAHMER, 1997, p. 1). Its main objective is the promotion of application-oriented research and development as well as the use of $R \& D$ results in the form of new technology in industry. It is thus the application arm of science policy, aiming at bringing scientific ideas to technological solutions. Both science and technology policy are often associated with the establishment of research capacities, the creation of new ideas in basic research or the support of pioneering industries creating new technological trajectories. The terms are therefore often used to denote policies targeting budget-intensive, input related activities in the innovation process.

Innovation policy, in contrast, represents policies targeted at the intersection of science and technology policy (MEYER-KRAHMER, 1989, p. 1). Referring to a broad definition of innovation, innovation policy denotes all policies aimed at the support of research and development from the first generation of an idea up to its introduction onto the market. The term innovation policy thereby addresses not only the scientific and technological but also the economic, organisational and social aspects needed for and caused by innovation activities. With regard to the chain-linked model of the innovation process, innovation policy is more (or at least equally) about ensuring the necessary linkages than about ensuring the provision of inputs. 


\section{STATEMENT OF RESEARCH QUESTIONS}

The presented argument shows that it is unlikely that any one-dimensional answer can be found for the question how to best set-up a multi-level, multi-actor governance system. To structure the qualitative case study analysis, it seems therefore expedient to formulate five research questions addressing the nature and implications of STI policy design in a multi-level, multi-actor governance framework.

RQ 1: Is it true that a strengthening of science, technology and innovation policy making can be observed at the regional level? Does this process constitute new regional entities or is it integrated into a pre-existing governance structure and thus bound to preexisting entities?

Rationale for RQ 1: The EU Commission is now not only involved in classical regional policy, but is also intensifying its science, research, technology and innovation policy aimed at regions (EUROPEAN COMMISSION, 2001, 2005) in pursuit of the European Research Area and in order to reach the Lisbon and Barcelona objectives (3\% objective). Similarly, political decentralisation tendencies prompted by some European countries and the EU itself lead to an additional strengthening of the regional policy level. The academic literature suggests that regional governments have thus become an important actor in the science and technology governance system (LYALL and TAIT, 2004).

RQ 2: Is science, technology and innovation policy design at the regional level hampered by a lack of strategic information and/or does it lack an integrated national perspective?

Rationale for RQ 2: Since policy is now designed at both national and regional lev- 
els the conflicting targets of regional and national policy actors have entered the bargaining process of STI policy making from which they were previously absent. While at the national level intensified global competition increasingly demands spatial concentration and regional specialisation of innovative economic activity, regional policy measures are likely to be inspired by regional development objectives which often translate into the desire to develop as many regional strengths as possible. There is therefore a real danger that the increasing regionalisation of STI policy could compromise the overall efficiency of national innovation systems if it is pursued without the simultaneous adaptation of the embedding multi-level governance processes.

RQ 3: Is it the case that the diverging political interests of the actors on the national and the regional level will limit the amount of policy co-operation even though coordination could generally benefit all levels?

Rationale for RQ 3: On the one hand, regional policy makers are typically legitimated (i.e. elected) at the regional level so that their main aim will naturally be to satisfy their voters by providing visions for the improvement of local economic development. The non-elected English Regional Development Agencies (RDAs) provide an obvious exception to this assertion (PERRY, THIS ISSUE). Considerations of national efficiency may often run counter to this agenda, especially for economically weaker regions which would be disadvantaged if all funding were to be optimally allocated. On the other hand, regional policy actors such as regional development agencies or ministries in federal states typically command fewer resources than those at national level. Hence national policy actors often have a higher capability to develop strategic policy frameworks. Likewise it is relatively easy for them able to collect data on and evaluate the 
plethora of STI policies applied in the country. They can thus much more quickly identify redundancies which is a relatively difficult task for the smaller (and often competing) sub-national actors.

RQ 4: Is it the case that national STI policy can provide important guidance for STI policy design at the regional level, while regional STI policy actors can activate potentials inaccessible to outsiders? Has the realisation of policy co-ordination led to concrete positive outcomes?

Rationale for RQ 4: The newly emerged multi-level governance structure nevertheless raises the questions of if, and in what form, an accommodation of conflicting interests can be achieved, so that the necessary co-ordination of STI policy becomes possible. It appears that in certain areas of STI policy substantial complementarities exist that can be activated by a cooperation of national and regional policy actors.

RQ 5: Is it the case that the element of STI policy addressed strongly influences the potential for and possible efficiency of science, technology and innovation designed at a regional level?

Rationale for RQ 5: This need for differentiation has raised the question of which policy measures produce similar or even greater efficiency, effectiveness and additionality when they are designed at a regional level. In this context it is important to take into account which field of science, technology and innovation policy should is addressed by the STI policy measure in question.

\section{METHODOLOGY}

Since national opinions diverge as to how much independence certain regional entities are entitled to, the degree of regional autonomy varies significantly between politi- 
cal systems (GIODARNO and ROLLER, 2003). Consequently, no "representative sample of regional governance structures of STI policies" can be presented (TÖDTLING and TRIPPL, 2005) to corroborate the hypotheses listed above.

The authors of this paper, however, hold that evidence from the German federal system, which has a long record of regionalised STI policy, can contribute to a better understanding of the problems and opportunities created by regional STI policy making in a multi-level governance system. Even if the German federal governance system cannot be compared directly to those of other European countries, it should still be possible to draw valuable conclusions from Germany's experiences. While idiosyncratic in their form of occurrence, successes and failures in the German system highlight general problems and their possible solution on a more conceptual level.

To illustrate the complexity and necessary pre-conditions for the regional governance of science and innovation in a country with a long record in the devolution of political powers, a case study will be presented using evidence from Bremen as the smallest federal state (Land) in Germany. The findings draw on data collections carried out by the authors within the ERAWATCH prototyping phase in 2004, a project on behalf of the European Commission aiming at the analysis of the progress of the 3 per cent objective in 11 European regions (NAUWELAERS and WINTJES, 2005).

Bremen was selected because it is characterised by a strong regional government and possesses budgetary competences which allow the formulation and implementation of its own science and innovation policies. However, the Bremen economy shows several weaknesses and, in contrast to its budgetary power, its actual financial situation is poor and strongly contingent on national cross-subsidies. While Bremen is thus legally enti- 
tled to authorise high volume STI policy expenditure, the actual funding stems predominantly from external sources, which adds weight to the issue of national efficiency. Whether sufficient resources exist in terms of strategic intelligence and policy learning capability remains open to debate. Bremen is certainly also a regional entity in which the spatial scope of regional governance and the spatial scope of the economic actors active in the regional innovation system do not coincide.

It is this set of framework conditions that makes the regional promotion of science and innovation in Bremen a difficult task. Even if it is not possible to clearly answer the question of the effectiveness of Bremen's regional STI policy within the limits of this paper, the authors hold that it can indeed shed some light on the more general question of which aspects of the innovation process should be regulated and enabled by STI policies designed at the regional level.

\section{THE GOVERNANCE OF SCIENCE AND INNOVATION IN}

\section{GERMANY}

\section{POLICY LEVELS AND DIVISION OF TASKS IN A FEDERAL SYSTEM}

The division of competences between the national government and the federal states is fixed in Germany's basic law ("Grundgesetz") and aims to prevent a renewed concentration of power. According to Article 30 of the basic law, "the practice of the national powers and the fulfilment of the national tasks are matter of the federal states, as far as this Basic Law makes or permits no other regulation." Each federal state has its own school and higher education laws, as well as ministries for cultural affairs or science. A crucial element of the science policy of the Länder is the financing and organisation of 
higher education (HÉRAud and KOSCHATZKY 2006). Around $60 \%$ of the total German expenditures for science of $€ 32.3$ billion (2003) are borne by the Länder, $34.5 \%$ by the federal government and $5.2 \%$ by scientific non-profit organisations (BMBF, 2005, p. 12). In 2003 funding of the universities and the university hospitals amounted to $86.3 \%$ of the total science expenditures of the federal states. (BMBF, 2005, p. 20). In order to enable all federal states to create as equal living conditions as possible in all regions of Germany, the Finanzausgleich or fiscal equalisation payment is an instrument to redistribute financial means from financially strong to financially weak federal states in order to achieve the balance objective (DöRING, 2005).

With regard to education, science and research policy the standing conference of the ministers of education and cultural affairs (KMK) is another important coordination body. The KMK pursues the following objectives: agreement of comparability of certificates and examinations; securing of quality standards for schools, vocational training, and universities; promotion of cooperation between education and scientific organisations. The necessary coordination among the federal states usually takes place via recommendations, declarations and/or state agreements.

Although the federal states are involved in science, technology and innovation policy, the essential impulses come from the federal government level, especially from the ministries of education and research $(\mathrm{BMBF})$ and of economics and technology (BMWI). This situation is comparable with other federal states, such as Canada (SALAZAR AND HOLBROOK, THIS ISSUE). The BMBF and BMWI budgets for institutional promotion and promotional programmes are much greater than those of the single Länder. With the sum of $€ 7.06$ billion (2003), the BMBF receives approx. $63 \%$ of the 
federal government funds spent on science, research and development, the ministry of defence $11.3 \%$ ( $€ 1.26$ billion) and the ministry for economics and labour $9.7 \%$ ( $€ 1.08$ billion).

For historical reasons, i.e. the creation of a federal system after WW II, practically identical structures of political governance for science and innovation exist in the 16 federal states (ministries, official bodies, organisations). In these multi-level governance structures, horizontal coordination between the single states is necessary in order to articulate common federal states positions against the federal government, but as well vertical coordination between the states and the federal government in cases where both levels share responsibilities, e.g. in the distribution of tax revenues or in investments in the university infrastructure.

In recent years, an attempt was made to reform the federal system including the promotion of scientific research. The objective of these reform efforts is not a return to a centralised state, but to reduce the complex distribution of responsibilities between the various political levels in Germany (GöNNER, 2004). Due to the complex German governance structure quick results cannot be expected (for spatial aspects of the German federalism cf. FÜRST and KILPER, 2005).

Regarding science policy and regional development, there are two important interfaces between the federal and the Länder governments. The first one is the "joint task university building". Since 1970, the extension and new building of universities, including the university hospitals, are regarded as an area in which the federal government cooperates in fulfilling the tasks of the Länder, if this task is of significance for the population as a whole and this cooperation is necessary to improve the quality of living. 
From 1970 till 2004 a total of approx. $€ 56.2$ billion was invested, whereby the central government and the states usually shared the costs 50-50\% each. The second interface is the joint task of the "improvement of the regional economic structure" (DEUTSCHER BundeStAG, 2004). Admittedly, implementing promotional measures is the responsibility of the states, but the necessary framework plan is drawn by the federal government and the states together. The funds for the joint task are decided every year by the federal and Länder parliaments in the framework of the annual budget legislation. The federal government and the states participate equally in the financing of the joint task. The focus lies in the area of regional structural policy, but in past years the significance of research, development, technology transfer and innovation has increased (KOSCHATZKY, 2002).

\section{AUTONOMY AND SCIENCE POLICY GOVERNANCE COMPETENCES IN BREMEN}

Bremen is a federal state with all the autonomy this status offers. It is an old Hanseatic town and thus trading city, with overseas trade contributing to wealth and income for many centuries. 663,000 inhabitants, a share of $0.8 \%$ of the total German population, in an area of $404 \mathrm{~km}^{2}$ make for a population density of 1,633 inhabitants/ $\mathrm{km}^{2}$. Since the 1970s and 1980s, Bremen underwent a substantial economic crisis because of heavy employment losses in shipbuilding, harbour services, car manufacturing and engineering. With $0.4 \%$ of the total employment in agriculture, $22.7 \%$ in industry and $76.9 \%$ in services (ARBEITNEHMERKAMMER BREMEN, 2004), Bremen is a pronounced service economy. Its GDP per capita is $49 \%$ higher than the EU-25's average, while GDP growth in the years 1995 to 2001 is relatively low with only $1.5 \%$ annually 
(EUROPEAN COMMISSION, 2004, p. 188). Nevertheless, Bremen has the highest unemployment rate of all federal states in former western Germany, reaching around 13 per cent.

Due to financial compensation payments from other federal states (according to the Fiscal Equalisation Law among the states), which made Bremen a net receiver of public funds for many years, the budgetary income situation is relatively stable. But since the compensation scheme was changed from 2005 onwards, Bremen has lost a certain, so far not quantifiable, share of this income source (POHL and SÜNNER, 2001).

The regional government, called "Senat", is an elected government that has its own legal and financial rights. Due to the fact that Bremen enjoys a relatively high degree of autonomy, the regional government is responsible for research and education at the university and possesses science policy competences. The ministry of education and science and the ministry of economic affairs and ports are the major actors in R\&D and innovation policy and can arrange their own support programmes (FREE HANSEATIC CITY OF BREMEN, 2004). In relation to coordination activities with upper or other policy levels, Bremen is no exception from the German rule. The state is a member of the federal council, the standing conference of the ministers of education and cultural affairs, and also of several federal government and Länder committees (e.g. for research and technology).

According to recent data from Eurostat's New Cronos Database, Bremen's gross expenditures on R\&D (GERD) reached $2.72 \%$ of GDP in 2003. This is above the EU-15 average of $1.95 \%$ GERD per GDP, and also above the German average of $2.52 \%$. In Germany, the most R\&D-intensive regions are Stuttgart with $4.66 \%$ GERD per GDP 
and Upper Bavaria (Munich) with $4.60 \%$. In Bremen, expenditures on R\&D in public research and higher education institutions and the business enterprise sector are nearly identical ( $1.32 \%$ and $1.40 \%$ of regional GDP respectively), which again indicates a relative strength of the public sector in R\&D activities. The German average of industrial R\&D reached $1.76 \%$ of GDP in 2003. Among the publicly funded R\&D expenditure in Bremen, $0.69 \%$ is accounted for by university spending and $0.63 \%$ by the expenditure of non-university institutions. In Stuttgart, in comparison, public R\&D expenditures account for only a tenth of the overall $R \& D$ expenditure in the region.

Although Bremen can be characterised by a less R\&D-intensive manufacturing sector according to the German average, a few exceptions exist. Bremen is one of the most important locations for the German aerospace and aeronautics industry. Approx. 1,800 people are employed in the highly qualified R\&D sector - which accounts for approx. $40 \%$ of all German employees in this sector. A key player is the European Aeronautic Defence and Space Company, EADS (Airbus Germany and EADS Space Transportation Bremen). The core range of companies, without ancillary industries, thus employs about 4,500 mostly highly qualified persons. It is supplemented by other local R\&Dintensive SMEs. The DaimlerChrysler car manufacturing plant is the second largest in Europe (16,000 persons employed) and the sports cars SLK, CLK and SL are manufactured in Bremen. But in general, manufacturing enterprises are characterised by few inhouse R\&D activities (KOSCHATZKY et al., 2004). In addition, the few "big players" of Bremen's manufacturing sector are subsidiary plants with no or small R\&D activities (e.g. steel industry, automobile industry, food production) and there are no or few pronounced linkages to the regional science sector. 
Major public R\&D actors in Bremen are the University of Bremen, the private International University of Bremen (IUB), the University of the Arts and the universities of applied science, in both Bremen and Bremerhaven. Nearly 35,000 students are registered at Bremen's universities altogether. The University of Bremen is one of the German universities most successful in attracting third party funding. $30 \%$ of its total income amounting to $€ 245.1$ million (2004) stem from promotional institutions and enterprises. The private IUB, for which the city state provided EUR 110 million of initial financing in 1999 will soon be renamed Jacobs University following the proclamation of a EUR 200 million investment by the Swiss Jacobs Foundation, the largest donation ever given by a private foundation to a science institution in Europe. It is thus exemplary as one of the first notable public-private partnership in science and education in Germany.

Other national public research organisations like Max-Planck and Fraunhofer Institutes and a large variety of internationally renowned regional research institutes, complement the public research system of Bremen. In infrastructural support, the technology park has to be mentioned, which was established by the end of the 1980s. On a total area of 150 hectares are concentrated: the University of Bremen with its 12 faculties; 14 research institutes with about 600 employees; the technology and incubation centre "BITZ" with about 50 enterprises and 250 employees; and 350 companies with 6,000 employees (WILLMS, 2003; KOSCHATZKY, 2004).

In 2002, the total public research budget in Bremen amounted to $€ 265.5$ million, a decrease of $€ 30.8$ million compared with 1999 (cf. Table 1). The federal government's contribution was $64 \%$. Although the Bremen state government slightly raised its re- 
search budget compared with 2001, the decrease in the research budget can be traced back to fewer funds coming from the federal central government. These rose again clearly in 2003 however, so that the year 2002 presents a budget-technical exception. Table 1 shows that Bremen possesses its own research budget and thereby a relatively high autonomy in STI policy, but the crucial cash flows stem from the federal government. This situation is comparable to that of other European autonomous regions with high levels of governance responsibilities (KOSCHATZKY, 2005b), which receive transfer payments from the national government and are able to implement their own policies to a large extent with these funds.

$<$ Table 1 about here>

It becomes clear that the city state of Bremen is characterised by a high degree of autonomy in policy design. It possesses its own ministries, e.g. for research and trade and industry, which again have their own budgets and programmes to promote science and innovation. These budgets are not exclusively financed through regional funds; there is a dependency on funding coming from the federal government. However, Bremen possesses full responsibility for these budgets so that this dependency hardly hampers its political autonomy.

Given the sectoral structure and the lack of dynamism in regional industry, which is characterised by an under-average research intensity, it could be said that the regional government in Bremen has expanded the public research sector to the best of its ability. On the other hand, this could also be seen as a questionable effort to compensate for a 
regional industrial research deficit by the expansion of regional public science and innovation activities. In Bremen, many STI relevant policy priorities are only coordinated within the region (e.g. higher education, business development and fiscal policy). On an inter-regional level information is exchanged with the government of the adjacent federal state of Lower Saxony, but little active coordination takes place.

With respect to the first research question (RQ 1) it can therefore be stated that the case of Bremen documents a broadening of responsibilities and a strengthening of already strong resources for regional STI policy making - on the level of a pre-existing regional administrative entity. The city state's actual implementation capacity, however, remains subject to its overall budgetary situation which is susceptible to tax income fluctuation and cannot be completely controlled by regional policy makers.

\section{OBJECTIVES, POLICY INSTRUMENTS AND COORDINATION}

With respect to the second research question (RQ 2) it can be stated that during the last 10 years, Bremen has been able to implement a variety of regionally designed STI policies.

One of the most prominent examples of regionally designed STI policy in Bremen is the framework for regional science, technology and innovation policy until the year 2010, through the programme "InnoVision 2010". It was jointly formulated by the ministry of education and science and the ministry of economic affairs and ports. Its major objective was to make Bremen one of the top 10 German technology regions in 2010. InnoVision addresses science, technology and innovation objectives by investing in the scientific infrastructure, by focussing on selected technology fields and by fostering regional networking and firm formation activities. This target, however, appears overly 
ambitious given that among 117 German cities surveyed in 2001-2003 the city of Bremen ranked $24^{\text {th }}$ in terms of $R \& D$ input and $28^{\text {th }}$ in terms of R\&D output (STENKE and WILLMS, 2004, pp. 3-4). In view of these performance indicators and on necessary budget adjustments, a reassessment process of the programme was started in 2004 .

According to the original planning, around $€ 34$ million per annum was devoted to R\&D from 2002-2010. Due to decreased tax income and an anticipated reduction in transfer payments from other federal states, the funding had to be abated drastically. For the remaining years from $2005-2010$ only $€ 5$ million per annum are still available for R\&D funding.

The setting of overambitious goals suggests that Bremen's regional STI policy has in the past been characterised by independent agenda setting (RQ 2). However, policy makers have likely been aware that the goals were unattainable and used them as a motivational tool. A cross-the-board characterisation of Bremen's regional STI policy as uninformed does therefore not seem justifiable. However, the described agenda setting does seem to confirm that regional STI policy making in Bremen is not driven by an integrated national perspective but by regional ambitions. To take an efficiency-oriented integrated national perspective would have meant to renounce the development of regional capacities that can better be performed by other states - an approach of little appeal to the regional policy makers trying to promote and develop their city state.

A second finding is that the continuation of the programme InnoVision 2010 which has been labelled "Development Strategy for the High-Tech Region Bremen" has come with a significant concentration of resources. While "InnoVision 2010" envisaged eight science and technology areas in which competence clusters should be created (tele- 
communication and information technology, media and entertainment (T.I.M.E.), health economy, environmental technology, space and aeronautics, logistics, blue biotechnology and design) (FreE HANSEATIC City OF BREMEN, 2004), the reassessment of the project has narrowed down the focus to the following five areas: mobile solutions, elogistics, innovative materials, ecological intelligence (e.g. offshore wind energy, ocean research) and future market health care (TIMM and GUNDRUM, 2005). Due to its integration in international corporate networks, the space and aeronautics industrial sector is still an important policy issue in Bremen, but not subject of regional intervention by the InnoVision programme. This reaction additionally suggests that the regionalisation of science, technology and innovation policy in Bremen has led to a lack of focus so strong that it has been acknowledged by the very actors who designed it in the first place. Given the size of the regional economy a spectrum of eight focal sectors appeared far too broad.

The observed regional STI policy supports the notion that policy makers do not display a strong motivation to establish inter-regional cooperations (RQ 3). Additionally, regional STI policy has probably supported sectors which are unlikely to attain interregional competitiveness. However, the revision of the InnoVision 2010 programme can be regarded as an indication that a process of policy learning seems to be underway in this respect.

Having thus pointed to the major shortcomings of past regional science, technology and innovation measures - predicted by theoretical considerations above - it is equally important to mention that Bremen does indeed display certain strengths which have enabled certain actors to successfully take part in competitions for funding from the na- 
tional level (the BMBF), i.e. enabled regional actors to take part in multi-level governance processes coordinated by policy making at the national level. This is, among others, true for the participation of Bremen as one of the 15 network regions in the programme EXIST, which supports the formation of university spin-offs by a regional network approach (KULICKE, 2006). Although Bremen displays below average firm formation activities compared to other federal states, the Bremen network BRIDGE (University initiative Bremen for the promotion of entrepreneurial spirit and firm formation) successfully implemented teaching and entrepreneurship education programmes in Bremen's universities and contributed to an increased awareness about the importance of firm formation for the regional economy. The example of Bremen confirms the notion that conflicts of interest between the national and the regional level are not inevitable but can be resolved by proper coordination and the 'co-evolution' (SotARAUTA AND KAUTONEN, THIS ISSUE) or focusing of policy agendas (RQ 4). In this respect the competitive programmes of the BMBF provide an example of good practice.

In view of both the fourth and fifth research questions (RQ 4 and RQ 5) it must also be stressed that Bremen does indeed provide a best practice example in certain areas of STI policy related to the use of regional intelligence to activate regional potentials. The interactive process that was initiated for the reassessment and adaptation of InnoVision 2010 as well as the efficient organisation of the STI policy support institutions demonstrate that Bremen works successfully in policy areas which do not depend on extensive funding but on the political capability to improve organisational structures and processes.

An essential feature of InnoVision 2010 and the new development strategy for Bre- 
men is the targeted linking of regional science areas with innovation fields directed at enterprises. This requires a close collaboration between the ministries of economic affairs and science and education. It is not the rule in Germany that science and economics ministries in the federal states cooperate closely in joint programmes like InnoVision 2010. For this reason, the case study of Bremen can be regarded as an example of good practice for a policy coordination process between scientific and economic policy interests. The technology advisor of the regional government provides the link. He is the former president of the University of Bremen and has many and varied contacts to the science, enterprise and political communities. Bremen as a small region has an advantage here because the number of organisations, stakeholders and actors, and thus of possible interfaces, is limited. Networking is working well this way, exploiting the advantages of spatial proximity. The evidence thus indeed shows how the regionalisation of STI policy in Bremen has led to both desirable and less desirable developments. While certain ambitious attempts to develop a quasi-autonomous STI policy focusing on science policy measures have clearly failed, it is equally evident that a lot of regional intelligence has indeed been put to use.

In line with the fears raised in RQ 2 it could be demonstrated that policy makers in Bremen put too much emphasis on the broad development of the regional science base rather focussing on the support of existing (or nascent) centres of excellence by means of innovation policy such as networking, marketing and technology transfer. From the perspective of the economy as a whole, therefore, doubts remain whether the regional science policy in Bremen has so far been conducive to the overall efficiency of the national innovation system. In view of the fate of InnoVision 2010 it appears questionable 
whether Bremen, with its science budget depending on external framework conditions and its regionally oriented policy priorities, possesses the necessary financial and human resources to build up a research infrastructure which is both comprehensive and competitive. To the contrary, it seems likely that a concentration of the available resources, i.e. a focusing of the policy, would be a more promising strategy.

With regard to the theoretical argument the case study thus clearly demonstrates that in Bremen,

- regional STI policy has a tendency towards setting overambitious and unfocused goals due to independent policy agenda-setting, oriented towards regional development (RQ 2, RQ 3);

- national STI policy can provide important guidance and information for policy makers at the regional level. For example, competitions for (significant) national funding can help to direct regional efforts towards areas of local strength. Especially in the light of budgetary restrictions, this seems important to avoid wastefully spending funding in areas where the region does not possess a competitive edge (RQ 4);

- regional STI policy making is especially difficult in the field of science policy and competence building which require large sums of investment. This is especially the case in regions that do not command sufficient self-raised resources and are thus susceptible to changes in transfer income (RQ 5);

- regional STI policy can nevertheless make an important (and possibly more important) contribution in policy areas that depend less on funding than on regional intelligence (i.e. familiarity with the local situation). While regional actors may not 
equally be able to implement large competence building measures in the field of science policy, their knowledge is an important and possibly indispensable asset for modern innovation policy (RQ5).

Nevertheless, the example of Bremen also shows that there is no clear cut dichotomy between STI aiming at regional balance, and efficiency oriented policies resulting in stark regional specialisation. Even a small city state such as Bremen can successfully participate in national competitions for research and innovation funding. The sometimes raised fear that a national STI policy focused at regional specialisation will necessarily increase the number of regions dropping out into a technological periphery may therefore be overstated (CF PERRY AND MAY, THIS ISSUE). The reconciliation of seemingly conflicting political agendas through coordination thus appears an effort worthwhile.

\section{CONCLUSIONS}

In today's multi-level governance system the governance of science and innovation poses complex demands on regional governments. The building of a competitive research infrastructure requires not only autonomous decision-making powers, but also adequate strategic intelligence and policy learning capability. A fundamental challenge exists in the coordination of a region's own measures with those on other political levels and in the strategic use of promotional funds (EU, national government) to meet its own targets.

On the political stage, such as in the German federal system, for example, decision making is often led by the hypothesis, that each - even small - regional entity possesses the ability to design its own science, technology and innovation policy. Empirical evidence, in contrast, supports the assumption that a mere regionalisation of STI policy 
tends to lead to unfocused policy measures and redundancies. It illustrates that not every region can fulfil the task of STI policy design to the same extent.

One important restrictive factor is the budget for science and research that is at the disposal of regional governments. Others factors include strategic intelligence and policy learning capabilities. Accordingly few regional governments are in the position to build up a science and research infrastructure (i.e. to create new regional strengths) which can subsequently survive in international competition (TöDTLING and TRIPPL, 2005). This is especially the case since important players in the field such as nonuniversity research institutions tend to be financed and controlled from the national level.

With a view to the shortages in public budgets in many small regional entities, but certainly in other regions as well, the question is therefore which field of science, technology and innovation policy is the appropriate playing field for policy measures designed at a regional level. Evidence from Bremen suggests that science policy aimed at creating new centres of excellence, with high budgetary demands, is a less appropriate field than innovation policy aiming to improve networking in existing areas of strength. Science policy often requires large investments and strategic far-sightedness that is not, or at least not constantly, available in smaller or financially weak regions. With a view to the diversity of regional economic potentials and structures, innovation policy clearly is the more appropriate side of the coin for regional policy approaches in regions with small budgets or with limited governance capabilities. Innovation policy in this respect is understood as policy that focuses on technology transfer, commercialisation and on networking in the innovation process. It addresses mid- to end-of-pipe activities, chan- 
nelling the pre-stage science and technology policy measures to market-ready solutions by a variety of often low-budget information, technology transfer or marketing activities. With the design of innovation policy instruments based on regional intelligence, regional governments can both activate regional potential to create regional value added and jobs, and make an active contribution to the improvement of the overall efficiency of the national innovation system. The agendas of regional and national STI policy makers may therefore be less conflicting than sometimes perceived. Correspondingly, empirical evidence indicates that STI policy makers at the national level can provide mechanisms which encourage regional STI policy makers to direct their attention and funds towards the development of existing strengths, rather than the building of new profiles.

Even if the "innovation paradox" (OUGHTON et al., 2002) indicates that not all regions possess similar innovation policy competences, most of them will be able to design some innovation policies suitable to remove regional bottlenecks in the innovative and networking capacities of local enterprises. Few regions, and certainly not those at a NUTS-1 level, are void of any inter-regionally competitive sector on which they could focus their STI policies.

Consequently, the main point of this paper is that precisely when policy makers on a national level do not, or no longer, have the authority to centrally administer and structure STI policy, it is all the more necessary that they provide incentives for regional governments to focus their STI policy on certain areas with potential, to integrate themselves in inter-regional dialogue and to actively take part in national competitions. Regional actors should be discouraged to understand their science, technology and innova- 
tion policy as a substitute or a complement for regional policy aimed at equalisation.

\section{ACKNOWLEDGEMENT}

The authors would like to thank four anonymous referees for substantive comments. Moreover, the authors express their gratitude to Arlette Jappe, Vivien Lo, Beth Perry and Thomas Stahlecker for their support to this article.

\section{REFERENCES}

ARBEITNEHMERKAMMER BREMEN (Ed.) (2004) Statistisches Taschenbuch 2005. Wirtschafts-, Arbeits- und Sozialstatistik. Arbeitnehmerkammer, Bremen.

ASHEIM B.T. and GERTLER M.S. (2005) The Geography of Innovation. Regional Innovation Systems, in FAgerberg J., MOWERY D.C. and Nelson R.R. (Eds.) The $O x$ ford handbook of innovation, pp. 291-317. Oxford University Press, New York.

BENZ A. and EBERLEIN B. (1999) The Europeanization of regional policies: patterns of multi-level governance, Journal of European Public Policy 6, 32-48.

BMBF [BUNDESMINISTERIUM FÜR BILDUNG UND FORSCHUNG] (ed.) (2005) Forschungs und Innovation in Deutschland 2005. BMBF, Bonn, Berlin.

BRACZYK H.-J. and HEIDENREICH M. (1998) Regional governance structures in a globalized world, in BraczYK H.-J., COOKE P., Heidenreich M. and Krauss G. (Eds.) Regional Innovation Systems. The Role of Governance in a Globalized World, pp. 414-440. UCL Press, London.

BunNell T.G. and CoE N.M. (2001): Spaces and scales of innovation. Progress in Human Geography 25, 569-589. 
Charles D., Perry B. and Benneworth P. (Eds.) (2004) Towards a Multi-Level Science Policy: Regional Science Policy in a European Context. Regional Studies Association, Seaford.

Cole A. and Loughlin J. (2003) Beyond the Unitary State? Public Opinion, Political Institutions and Public Policy in Brittany, Regional Studies 37, 265-276.

Commission on Global Governance (1995) Our Global Neighborhood: The Report of the Commission on Global Governance. Oxford University Press, Oxford.

CoOKE P. (2001) Regional Innovation Systems, Clusters, and the Knowledge Economy, Industrial and Corporate Change 10, 945-974.

CoOKE P. (2002a) Knowledge Economies. Clusters, learning and cooperative advantage. Routledge, London.

CoOKE P. (2002b) Regional Innovation Systems: General Findings and Some New Evidence from Biotechnology Clusters, Journal of Technology Transfer 27, 133-145.

Cooke P., Boekholt P. and TöDtling F. (2000) The Governance of Innovation in Europe. Regional Perspectives on Global Competitiveness. Pinter, London.

CoOKe P., BraczYK H.-J. and HeIDENREICH M. (Eds.) (2004) Regional Innovation Systems. Second Edition. London.

CoOKe P., Roper S. and WyliE P. (2003) 'The Golden Thread of Innovation' and Northern Ireland's Evolving Regional Innovation System, Regional Studies 37, $365-379$.

Crespy, C., Heraud, J-A And Perry, B. (this issue) Multi-level governance, regions 
and science in France: between competition and equality. Regional Studies.

Deutscher Bundestag (2004) Unterrichtung durch die Bundesregierung. Dreiunddreißigster Rahmenplan der Gemeinschaftsaufgabe "Verbesserung der regionalen Wirtschaftsstruktur" (GA) für den Zeitraum 2004 bis 2007. Drucksache 15/2961. Deutscher Bundestag, Berlin.

DöRING T. (2005) Räumliche Aspekte von Föderalismus und Finanzausgleich - von der Allokations- und Verteilungs- zur Wachstumsperspektive, Raumforschung und Raumordnung 63, 109-122.

EDQuist C. (2005) Systems of Innovation. Perspectives and Challenges, in FAGERBERG J., Mowery D.C. and Nelson R.R. (Eds.) The Oxford handbook of innovation, pp. 181-208. Oxford University Press, New York.

ETZKOWITZ H. and LEYDESDORFF L. (2000) The dynamics of innovation: from National Systems and "Mode 2" to a Triple Helix of university-industry-government relations, Research Policy 29, 109-123

EUROPEAN COMMISSION (2001) The Regional Dimension of the European Research Area. European Commission (COM (2001) 549 final), Brussels.

EUROPEAN COMMISSION (2004) A new partnership for cohesion. Covergence, competitiveness, cooperation. Third report on economic and social cohesion. European Communities, Luxembourg.

EUROPEAN COMMISSION (2005) Building the ERA of knowledge for growth. European Commission (COM (2005) 118 final), Brussels. 
Free Hanseatic City of Bremen (2004) InnoVision 2010. Bremen's Innovation Programme. Bremen. Senator for Economic Affairs and Ports, Bremen.

FÜRST D. (2001) Regional governance - ein neues Paradigma der Regionalwissenschaften?, Raumforschung und Raumordnung 59, 370-380.

FÜRST D. (2006) The role of experimental regionalism in rescaling the German state, European Planning Studies 14, 923-938.

FÜRST D. and KILPER H. (2005) Räumliche Aspekte des föderativen Systems - eine Einführung, Raumforschung und Raumordnung 63, 89-98.

Giodarno B. and Roller E. (2003) A Comparison of City Region Dynamics in the UK, Spain and Italy: More Similarities than Differences?, Regional Studies 37, 911-927.

GÖNNER T. (2004) Das Parlament stärken, den Föderalismus reformieren, Die politische Meinung 410, 15-18.

HÉRAUd J.-A. and KoschATZKY K. (2006) Governance II: Regions, Universities, and Excellence in Europe, Regions 263, 8-9.

IAMMARINO S. (2005) An Evolutionary Integrated View of Regional Systems of Innovation: Concepts, Measures and Historical Perspectives, European Planning Studies 13, 497-519.

Jones M., Goodwin M. and Jones R. (2005) State Modernization, Devolution and Economic Governance: An Introduction and Guide to Debate, Regional Studies 39, 397-404. 
Kitagawa, F. (this issue) The Regionalisation of Science and Innovation Governance in Japan? Regional Studies.

KOHLER-KocH B. (1996) The strength of weakness: the transformation of governance in the EU, in Gustavsson S. and Lewin L. (Eds.) The Future of the Nation State, pp. 169-210. Nerius\&Santerus, Stockholm.

KLINE S.J. and RosenberG N. (1986) In An overview of innovation. In: Landau, R. and Rosenberg, N. (Eds.) The Positive Sum Strategy. Harnessing Technology for Economic Growth. Washington: National Academy Press, 275-305.

KOSCHATZKY K. (2002) Regionsorientierte Innovationspolitik und innovationsorientierte Regionalpolitik: Zwei Wege in die gleiche Richtung? Gesellschaft für Regionalforschung. Seminarberichte 44, 7-30.

KoschATZKY K. (2004) ERAWATCH prototyping Phase, ESTO Study No.2: Analysis on the regional dimensions of the $3 \%$ action plan. Regional report Bremen. IPTC, Seville.

Koschatzky K. (2005a) The Regionalization of Innovation Policy: New Options for Regional Change?, in FUCHS G. and SHAPIRA P. (Eds.) Rethinking Regional Innovation: Path Dependency or Regional Breakthrough?, pp. 291-312. Springer, New York.

KoschatzKy K. (2005b) Foresight as a Governance Concept at the Interface between Global Challenges and Regional Innovation Potentials, European Planning Studies 13, 619-639. 
Koschatzky K., JAPPE A., HeMer J. and Wolf B. (2004) Technologietrends und regionale Entwicklungspotenziale in den bremischen Innovationsfeldern. Fraunhofer ISI, Karlsruhe.

KUHLMANN S. (2001) Future governance of innovation policy in Europe - three scenarios, Research Policy 30, 953-976.

KUHLMANN S. (2002) Governance and Intelligence in Research and Innovation Systems. Universiteit Utrecht, Utrecht.

KULICKE M. (2006) EXIST - Existenzgründungen aus Hochschulen. Bericht der wissenschaftlichen Begleitung zum Förderzeitraum 1998 bis 2005. IRB-Verlag, Stuttgart.

LyALL C. and TAIT J. (2004) Foresight in a multi-level governance structure: policy integration and communication, Science and Public Policy 31, 27-37.

MEYER-KRAHMER F. (1989) Der Einfluss staatlicher Technologiepolitik auf industrielle Innovationen. Nomos Verlagsgesellschaft, Baden-Baden.

MeYer-Krahmer F. (1997) Technologiepolitik, in Ropohl D. and SchmiD A. (Eds.) Handbuch zur Arbeitslehre. Oldenbourg, München.

NAuwelaers C. (2000), Policy learning for innovation in European regions, paper presented at the RESTPOR conference September 5-7, Kashikojima, Japan.

NAuwelaers C. and WintJES R. (2003) Towards a new paradigm for innovation policy?, in Asheim B.T., IsAKsen A., NAuwelaers C. and TöDtling, F. (Eds.) Regional Innovation Policy for Small-Medium Enterprises, pp. 193-220. Edward Elgar, Cheltenham. 
NAuWelaers C. and WintJes R. (2005) ERAWATCH Prototyping Phase. ESTO Study No. 2 - Analysis on the regional dimensions of the 3\% Action Plan. MERIT, University of Maastricht, Maastricht.

Oughton C., Landabaso M. and Morgan K. (2002) The Regional Innovation Paradox: Innovation Policy and Industrial Policy, Journal of Technology Transfer 27, 97-110.

PERRY, B. (this issue) The multi-level governance of science policy in England. Regional Studies.

PERry, B. AND MAY, T. (this issue) Governance, science policy and regions: an introduction. Regional Studies.

POHL M. and SÜNNER I. (2001) Die Neuregelung des bundesstaatlichen Finanzausgleichs. Wirtschaftspolitische Bedeutung für Bremen, BAW Monatsbericht 10+11/2001. BAW Institut für Wirtschaftsforschung, Bremen.

Salazar, M. AND Holbrook, A. (this issue) Canadian STI Policy: the product of regional networking? Regional Studies.

Sotarauta, M. And Kautonen, M. (this issue) Co-evolution of the Finnish National and Local Innovation and Science Arenas: Towards a Dynamic Understanding of Multi-Level Governance. Regional Studies.

StenKe G. and Willms W. (2004) Innovationsbericht 2003. Benchmarkanalysen zu FuE-Potenzialen und Innovation im Land Bremen. BAW Institut für Wirtschaftsforschung, Bremen.

SwYNGEDOUW E. (2004) Globalisation or 'Glocalisation'? Networks, Territories and ReScaling, Cambridge Review of International Affairs 17, 25-48. 
Timm J. and GundRum U. (2005) Bericht des Technologiebeauftragten. Der Technologiebeauftragte des Senats der Freien Hansestadt Bremen, Bremen.

TÖDTLING F. and TRIPPL M. (2005) One size fits all? Towards a differentiated regional innovation policy approach, Research Policy 34, 1203-1219.

Willms W. (2003) Technologiepark Universität Bremen. Ergebnisse der Unternehmensbefragung 2002, BAW Monatsbericht H. 8, 1-12. 
1

2

3

4

5

7

8

9

10

11

12

13

14

15

16

17

18

19

20

21

22

23

24

25

26

27

28

29

30

31

32

33

34

35

36

37

38

39

40

41

42

43

44

45

46

47

48

49

50

51

52

53

54

55

56

57

58

59

60

41

Table 1: $\quad$ Financing and expenditures of $R \& D$ in Bremen by year and source (in €million)

\begin{tabular}{lcccc}
\hline & 1999 & 2001 & 2002 & 2003 \\
\hline $\begin{array}{l}\text { Financing of R\&D } \\
\begin{array}{l}\text { R\&D expenditures financed by the } \\
\text { federal government }\end{array}\end{array}$ & 197.3 & 200.5 & 169.5 & 209.4 \\
$\begin{array}{l}\text { R\&D expenditures financed by } \\
\text { state of Bremen }\end{array}$ & 98 & 90 & 95 & $\mathrm{n} / \mathrm{a}$ \\
$\begin{array}{l}\text { Total } \\
\text { Execution of R\&D }\end{array}$ & 295.3 & 290.5 & 264.5 & $\mathrm{n} / \mathrm{a}$ \\
$\begin{array}{l}\text { R\&D expenditures of } \\
\text { universities }\end{array}$ & 105.5 & 121.3 & 146.6 & $\mathrm{n} / \mathrm{a}$ \\
$\begin{array}{l}\text { R\&D expenditures of business } \\
\text { sector }\end{array}$ & 226 & 240 & $\mathrm{n} / \mathrm{a}$ & 250 \\
$\begin{array}{l}\text { R\&D expenditure of non- } \\
\text { university research }\end{array}$ & 120 & 129 & 145 & $\mathrm{n} / \mathrm{a}$ \\
\begin{tabular}{l} 
Total \\
\hline
\end{tabular} & 452 & 490 & 552 & $\mathrm{n} / \mathrm{a}$ \\
\hline
\end{tabular}

Source: BMBF (2005: 122ff.) 